\title{
New occurrences of the ragweed leaf beetle (Ophraella communa LeSage, 1986) (Coleoptera, Chrysomelidae) in Hungary
}

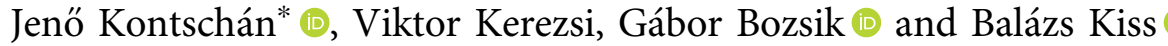

Plant Protection Institute, Centre for Agricultural Research, H-1525 Budapest, P.O. Box 102, Hungary

\section{BRIEF REPORT}

Received: October 18, 2021 • Revised manuscript received: October 19, 2021 • Accepted: October 19, 2021

Published online: November 16, 2021

(c) 2021 The Author(s)

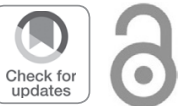

\section{ABSTRACT}

Fifteen new occurrences of ragweed leaf beetle (Ophraella communa LeSage, 1986) are presented from Hungary based on targeted faunistic investigations and the results of our call for citizen scientists. All records are concentrated on the nearby regions of Budapest, suggesting that the species was introduced to this northern central region of the country by human activity. The high number of new occurrences indicates that the species is steadily established in this region. In contrast, the natural dispersal from the neighbouring southern countries seems not to cross the Hungarian borders yet.

\section{KEYWORDS}

ambrosia feeding beetle, faunistic, citizen science, Hungary

\section{INTRODUCTION}

The chrysomelid ragweed leaf beetle (Ophraella communa LeSage, 1986) feeds mainly on ragweeds (Ambrosia spp.) (Futuyma et al., 1993). The species is native to North America, namely Canada, the USA and the Northern part of Mexico. It appeared in Europe in 2013; the first

\footnotetext{
*Corresponding author. E-mail: kontschan.jeno@atk.hu
} 
specimens were collected in Northern-Italy and South Switzerland (Müller-Schärer et al., 2014). The species was collected in Slovenia in 2017 (Seljak, 2017); in 2018 and 2019, it was found in Croatia and Serbia (Zadravec et al., 2019; Petrović-Obradović et al., 2020). In 2020, the ragweed leaf beetle was collected in Hungary in a southern district of Budapest (Soroksár), far from the known occurrences in the neighbouring countries (Horváth and Lukátsi, 2020). This geographically isolated record suggested a human introduction of the species to this area.

\section{MATERIAL AND METHODS}

We applied two different approaches for obtaining new records on the distribution of ragweed leaf beetle in Hungary. The first consisted of intensive species searching by plant inspections (singling) and netting on ragweed patches. The authors carried out these investigations in different regions of Hungary, including border territories close to the known occurrence of the species in Serbia and Croatia. The second approach was based on a public call in social media. Our call to share observations of ambrosia leaf beetle was sent to relevant Facebook pages, including entomological and institutional pages. We created an e-mail address (parlagfubogar@atk.hu) to receive the required information, like the date and location of the observations and pictures. The call contained a short description of the project and the species accompanied by photos.

\section{RESULTS}

From mid-July to mid-September of 2021, 15 new occurrences of ragweed leaf beetle were reported from Hungary. Most of them were situated in the eastern part of Budapest (Pest side), while two spots were located in the western part of the city (Buda). Two occurrences were located outside the territory of Budapest in Fót (north-east from Budapest) and Vecsés (southeast from Budapest); however, these two spots are also less than $10 \mathrm{~km}$ from the border of Budapest (Fig. 1).

Six of the 15 new localities were identified by the results of the citizen scientist call, but, interestingly, five cases originated from the same person. The other nine localities were identified by the authors (Table 1 ).

\section{DISCUSSION}

After the first record of O. communa in 2020 (Horváth and Lukátsi, 2020), several new locations are added here to the Hungarian distribution of the species. Contrary to the wide distribution of its primary host plant, the ragweed leaf beetle has not been collected at farther distances from the city of Budapest. Because Budapest is a transportation hub, we suppose that the ragweed leaf beetle was introduced involuntarily by transportation activity, probably from the southern direction, i.e., Serbia, Croatia or Slovenia. Despite the known occurrences of the species relatively close (c.a. $100 \mathrm{~km}$ ) to the Hungarian border in Serbia and Croatia (Zadravec et al., 2019; Petrović-Obradović et al., 2020), no specimens were found in the southern Hungarian regions. It is worth mentioning that the species occurred only in ruderal, urban habitats but not in agricultural areas, where its host plant, the common ragweed is also widely spread. 


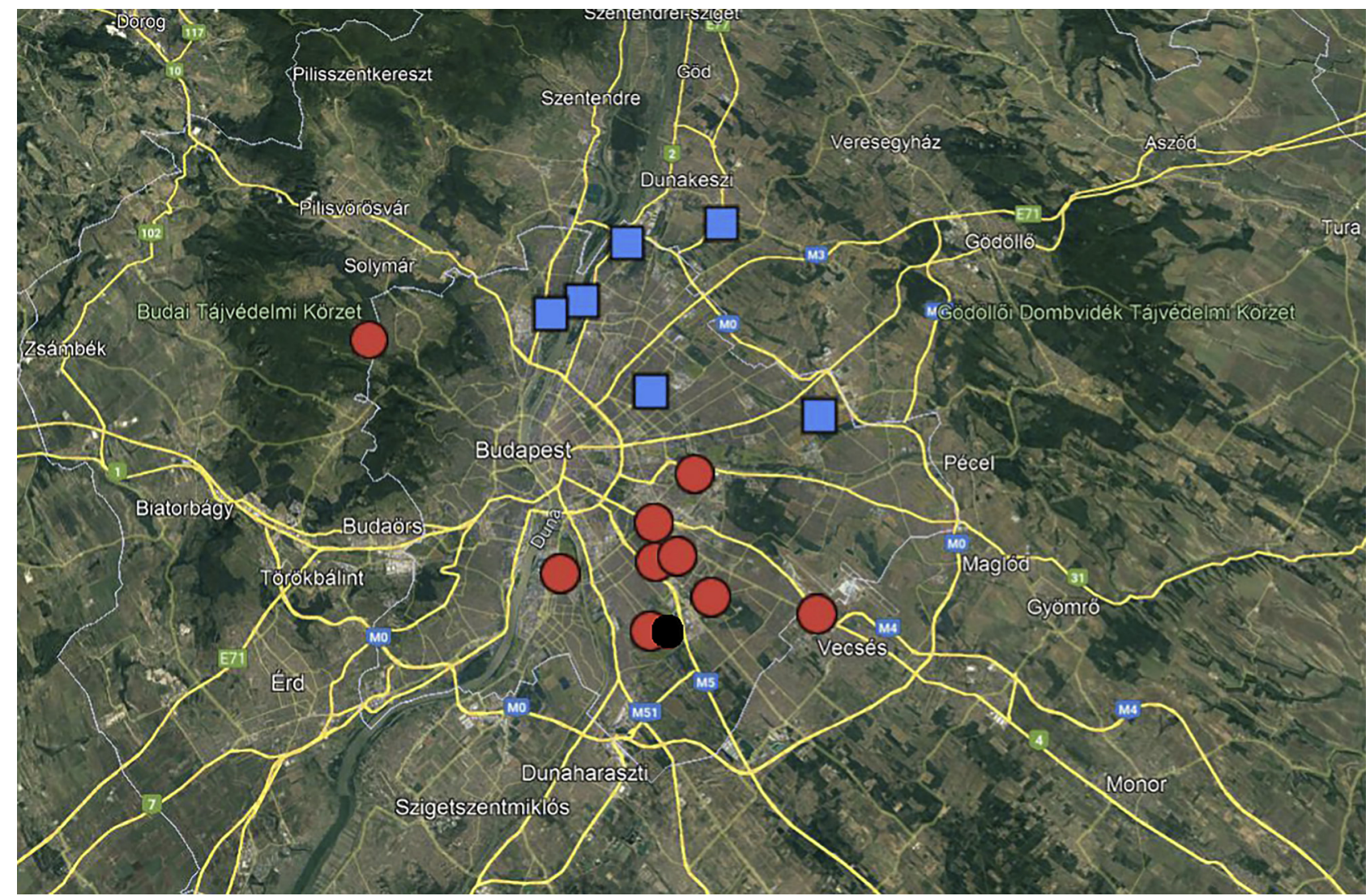

Fig. 1. The occurrences of ragweed leaf beetle (Ophraella communa LeSage, 1986) in Hungary (blue box: citizen scientist data, red dot: new data of the authors, black dot: first occurrence record (Horváth and Lukácsi, 2020) 
Table 1. The occurrences of ragweed leaf beetle (Ophraella communa LeSage, 1986) in Hungary in 2021 (u. $=$ streat $/$ road, patak $=$ stream)

\begin{tabular}{lcccc}
\hline City/Town & District & Road/streat/stream & Date & Collector(s) \\
\hline Budapest & II. & Nagykovácsi u. & 01.IX.2021. & Bozsik, G., Kerezsi, V., Kontschán, J. \\
& III. & Gázgyár u. & 31.IX.2021. & Körmendy, Z. \\
& IV. & Mogyoródi patak & 03.VIII.2021. & Körmendy, Z. \\
& IV. & Zsilip u. & 26.VIII.2021. & Körmendy, Z. \\
& X. & Maglódi u. & 06.IX.2021. & Kontschán, J. \\
& XVI. & Naplás u. & 21. VIII.2021. & Körmendy, Z. \\
& XVI. & Bartl János u. & 26.VIII.2021. & Szabó, E. \\
& XVIII. & Ipacsfa u. & 30.IX.2021. & Kontschán, J. \\
& XIX. & Jázmin u. & 17.VIII.2021. & Kontschán, J. \\
& XIX. & Kossuth L. u. & $31 . V I I I .2021$. & Kontschán, J. \\
& XIX. & Batthyány u. & 03.IX.2021. & Kontschán, J. \\
Fót & XXI. & Jókai u. & 09.IX.2021. & Kontschán, J. \\
Vecsés & & Nagyvárad u. & $28 . V I I I .2021$. & Körmendy, Z. \\
\hline
\end{tabular}

As the ragweed leaf beetle mainly occurred in the Mediterranean part of Europe (like Croatia, Serbia, Italy, and Slovenia) so far, it was questionable whether this species would be able to overwinter in Hungary. Because we found a population at the same locality as published by Horváth and Lukátsi (2020), we can confirm that the overwintering of the species was successful in 2020-2021.

We consider that the call for citizen scientists was relatively ineffective because only two people sent valuable data. Maybe the small size of the beetle or people's avoidance of the wellknown allergenic host plant caused the low number of observations by citizen scientists.

Based on the number of newly reported populations, we are convinced that the ragweed leaf beetle is steadily established in Hungary, and its distribution area will increase in the coming years.

\section{ACKNOWLEDGEMENTS}

This study was supported by the Hungarian National Food Chain Safety Office (NÉBIH). We are very grateful to Z. Körmendy and E. Szabó for the sent data.

\section{REFERENCES}

Futuyma, D.J., Keese M.C., and Scheffer S.J. (1993). Genetic constraints and the phylogeny of insect-plant associations: Responses of Ophraella communa (Coleoptera: Chrysomelidae) to host plants of its congeners. Evolution, 47(3): 888-905.

Horváth, D. and Lukátsi, M. (2020). First record of Ophraella communa in Hungary (Coleoptera: Chrysomelidae). Folia Entomologica Hungarica, 81: 73-79. 
Müller-Schärer, H., Lommen, S.T.E., Rosellini, M., Bonini, M., Boriani, M., Bosio, G., and Schaffner, U. (2014). Ophraella communa, the ragweed leaf beetle, has successfully landed in Europe: fortunate coincidence or threat? Weed Research, 54(2): 109-119.

Seljak, G. (2017). Ophraella communa Le Sage, 1985 - ambrozijev lepenec. Biotska raznovrsnost Slovenije. Avaialable at http://www1.pms-lj.si/animalia/galerija.php?load=5263 (Accessed 24 September 2018).

Petrović-Obradović, O., Smiljanić, D., and Čkrkić Matijević, M (2020). Ophraella communa (Coleoptera: Chrysomelidae) has arrived in Serbia. Acta Entomologica Serbica, 25(2): 101-104.

Zadravec, M., Horvatić, B., and Prpić, P. (2019). The Balkans invaded - first record Ophraella communa LeSage, 1986 (Coleoptera: Chrysomelidae) in Croatia. Bioinvasions Records, 8(3): 521-529.

Open Access. This is an open-access article distributed under the terms of the Creative Commons Attribution 4.0 International License (https://creativecommons.org/licenses/by/4.0/), which permits unrestricted use, distribution, and reproduction in any medium, provided the original author and source are credited, a link to the CC License is provided, and changes - if any - are indicated. (SID_1) 